2003-11-01

\title{
Live and let die: regulatory mechanisms in Fas-mediated apoptosis
}

James Curtin

Technological University Dublin, james.curtin@tudublin.ie

Thomas Cotter

University College Cork

Follow this and additional works at: https://arrow.tudublin.ie/scschbioart

Part of the Biochemistry Commons, and the Cancer Biology Commons

\section{Recommended Citation}

Curtin JF, Cotter TG. Live and let die: regulatory mechanisms in Fas-mediated apoptosis. Cellular Signalling. 2003 Nov;15(11):983-92. Review. doi:10.1016/S0898-6568(03)00093-7

This Article is brought to you for free and open access by the School of Biological Sciences at ARROW@TU Dublin. It has been accepted for inclusion in Articles by an authorized administrator of ARROW@TU Dublin. For more information, please contact arrow.admin@tudublin.ie, aisling.coyne@tudublin.ie,gerard.connolly@tudublin.ie. Funder: Irish Cancer Society and Enterprise Ireland 


\section{Live and let die: regulatory mechanisms in Fas-mediated apoptosis}

James F. Curtint, Thomas G. Cotter *

Tumour Biology Laboratory, Department of Biochemistry, Biosciences Research Institute, University College Cork, College Road, Cork, Ireland

+Current Address: School of Biological Sciences, Dublin Institute of Technology, Dublin 8, Ireland Received 31 March 2003; accepted 13 May 2003

\section{Abstract}

Activation of Fas receptor by Fas ligand causes caspase 8 activation and apoptosis in cells and is an important mechanism by which normal tissue homeostasis and function are maintained. Activation of caspase 8 is preceded by the formation of a death-inducing signalling complex (DISC), and a number of redundant mechanisms regulate DISC formation in vivo. Fas receptor is widely expressed in tissues, and dysfunction of the regulatory mechanisms in Fas receptor signalling has been reported in several diseases including autoimmune disease and cancer. This review aims to identify and discuss the various mechanisms employed by cells to alter their sensitivity to Fas-mediated apoptosis by regulating DISC formation. We also discuss a number of defects identified with Fas receptor signalling and the associated pathologies.

Keywords: Fas; CD95; Regulation; Death receptors; DISC; Gene expression

\section{Overview of Fas-mediated apoptosis}

\subsection{Apoptosis}

Apoptosis or programmed cell death is defined by morphological changes including cell shrinkage, chromatin condensation, nuclear fragmentation, membrane blebbing, and apoptotic body formation. More recently, central signalling pathways responsible for apoptosis initiation and progression have been identified. Integral to many forms of apoptosis are a family of at least 14 different cysteine proteases called caspases. Caspases are synthesised as inactive precursors called procaspases. Cleavage and activation of procaspases can occur following a variety of stimuli including DNA damage and death receptor activation [1 and 2]. Caspases can be classified as initiator or effector in function depending on the role they play in apoptosis. Initiator caspases are responsible for detecting and transducing various apoptotic stimuli by cleaving and activating effector caspases. The preferred cleavage site for caspases is after a four amino acid motif Asp-X-XAsp where $X$ can be any amino acid. Effector caspases cleave downstream targets that include DNA repair enzymes, cytoskeletal proteins and proteins involved in cell cycle progression [3]. These targets are responsible for implementing the downstream pathways that culminate in morphological changes associated with apoptosis and loss of cell viability [4].

\subsection{Death receptors}


Death receptors belong to a superfamily of receptors involved in proliferation, differentiation and apoptosis called the Tumour Necrosis Factor (TNF) superfamily [5]. Death receptors are type I integral receptors with a conserved extracellular domain containing two to four cysteine-rich pseudo-repeats, a single transmembrane region and a conserved intracellular death domain about 80 amino acids in length that binds to adaptor proteins and initiates apoptosis [6, 7, 8 and 9]. Each receptor can bind with one or more than one type of ligand expressed on adjacent cells. Binding of ligand to receptor induces receptor trimerisation and clustering on the plasma membrane is required to initiate apoptosis in cells. At least six death receptors have been identified and described to date from homology and by loss of function studies. These are TNFR1 [10, 11, 12, 13 and 14], Fas (CD95/Apo1) [15], DR3 (TRAMP/Apo3) [16], DR4 (TRAILR1/Apo2) [17], DR5 (TRAILR2/TRICK2) [18, 19 and 20], and DR6 [21].

In addition to death receptors, three decoy receptors (DcR) have been identified. DcR1 (TRAILR3) [17] and DcR2 (TRAILR4) [22] are membrane bound receptors that bind with TRAIL. DcR3 [23] is a soluble receptor secreted by cells and binds with Fas ligand. Decoy receptors possess functional extracellular ligand binding domains but do not contain intracellular death domains and cannot recruit adaptor proteins required for apoptosis. The principle function of decoy receptors is modulating the sensitivity to death-receptor-mediated apoptosis in vivo [24].

A number of proteins involved in apoptosis can be recruited to death receptors through intermediate adaptor proteins that bind with the death receptors or other components of deathinducing signalling complex (DISC). Fas-associated death domain (FADD) [25 and 26], TNF-receptorassociated death domain (TRADD) [27], receptor-interacting protein kinase 1 (RIP1) [28] and deathassociated protein (DAXX) [29] contain death domains (DD) that recognise and bind with the corresponding DD on the intracellular surface of death receptors. These proteins function as adaptor proteins and it is believed that they create a scaffold to aid recruitment and binding of various other components of the DISC. The initiator caspases, caspase 8 and caspase 10 , interact with FADD through death effector domains (DED) present on both the caspase 8 and caspase 10 and also FADD. TRADD can recruit a number of adaptor protein death receptors including FADD, TNF-receptorassociated factor (TRAF) and RIP1. RIP1 interacts with caspase 2 and RIP associated protein with death domain (RAIDD), and DAXX can recruit the mitogen-activated protein kinase kinase kinase ASK1 [24 and 30]. The interactions between death receptors, their known ligands and intracellular adaptor proteins are summarised in Fig. 1.

\subsection{Role of Fas receptor}

Fas-mediated apoptosis can be regulated by a variety of signalling pathways in cells and is required for normal cell function. One of the principal roles of Fas receptor is regulating the immune response and this is the most clearly characterised function of Fas receptor. However, Fas receptor is expressed on most tissues and also plays an important role in regulating the function of many different tissues. A number of studies have illuminated the multiple modes by which Fas receptor signalling can regulate $T$ cell and B cell development, maturation and deletion [31, 32 and 33]. For example, activation of mature $T$ cells occurs during an adaptive immune response to an infection. Clonal expansion and subsequent deletion of activated T cells results from a process called activation-induced cell death (AICD). Increased Fas ligand expression is observed following T cell activation. However, cells are initially resistant to Fas-mediated apoptosis. During the course of the 
infection, activated T cells become progressively more sensitive to Fas-mediated apoptosis and this is ultimately required for AICD and for regulating the response of the immune system to a pathogen [34]. In addition, Fas-mediated apoptosis regulates other cells involved in adaptive immunity such as antigen-presenting cells [35 and 36], and is a principal mechanism by which cytotoxic T lymphocytes (CTL) induce apoptosis in cells expressing foreign antigens [37]. Dysfunction of Fas receptor is the underlying cause of autoimmune lymphoproliferative syndrome in humans [38 and 39]. Fas receptor-mediated apoptosis has been implicated in fulminant hepatitis [40], post-ischemic neuronal degeneration [41 and 42], during traumatic brain injury [43] and may also play a role in developmental apoptosis of various cells including embryonic motor neurons [44] and osteoclast formation [45]. Progression and metastasis of tumours is associated with resistance to Fas receptormediated apoptosis [46]. In addition, upregulation of Fas ligand often occurs in tumour cells following chemotherapy and may play a key role in immune evasion by eliminating infiltrating lymphocytes [47 and 48].

\subsection{Formation of the Fas DISC}

Activation of Fas receptor by Fas ligand initiates a caspase cascade culminating in apoptosis in sensitive cells. Effective formation of a protease complex called DISC is required in Fas-mediated apoptosis. At least four individual steps have been identified in Fas-sensitive cells following activation of Fas receptor with Fas ligand. Immediately following Fas receptor ligation with Fas ligand, microaggregates of Fas receptor form on the cell surface independent of caspase activity [49]. It has been demonstrated that trimerisation of Fas receptor is the minimal event required for FADD recruitment and effective DISC formation [50]. Subsequent DISC assembly occurs in type I cells and is dependent on reorganisation of cytoskeletal actin filaments. Activation of caspase 8 occurs following DISC formation and directly regulates the formation of large Fas receptor aggregates on the plasma membrane of cells and increased DISC activity. Finally, these large clusters of Fas receptor are endocytosed and recycled [49]. Type II cells have impaired DISC formation, and ceramide production is a necessary step for generation of large receptor aggregates and capping in lipid rafts [51].

Assembly of the components of the Fas DISC is a highly organised event and involves sequential clustering of adaptor and effector proteins at Fas receptor aggregates. FADD is recruited to and binds to the intracellular DD of Fas receptor in response to receptor trimerisation. Caspase 8 and caspase 10 bound to FADD are recruited to the plasma membrane and the increased local concentration of these proteases induces autocleavage and activation of caspase 8 and caspase 10 in trans. Caspase 8 appears to be the principal initiator during apoptosis because cells that were deficient in caspase 10 expression underwent normal apoptosis while resistance to Fas-mediated apoptosis was observed in caspase-8-deficient cells even when caspase 10 was overexpressed [52]. DAXX can also bind to the intracellular DD of Fas receptor and recruits ASK1. Activation of ASK1 was found to occur following recruitment to the DISC and subsequent JNK activation is believed to promote apoptosis in cells [53 and 54]. In addition, the interaction between DAXX and ASK1 was found to regulate caspase-independent cell death and was not dependent on ASK1 kinase activity [55 and 56]. The DD of RIP1 can also bind to Fas receptor and recruits RAIDD and caspase 2 to Fas receptor aggregates. Cleavage and activation of caspase 2 was found to promote the cleavage of effector caspases and regulate apoptosis [57]. 
Active caspase 8 can directly cleave and activate effector caspases in type I cells. However, very little caspase 8 is activated in type II cells and amplification of apoptosis is required. Cleavage of the $\mathrm{Bcl}-2$ family member BID by caspase 8 produces the pro-apoptotic tBID fragment that induces cytochrome c release from mitochondria and caspase 9 activation [58 and 59]. Expression of anti-apoptotic Bcl-2 family members can regulate the sensitivity of mitochondria to tBID and in turn the sensitivity of type II cells to Fas-mediated apoptosis [60]. Fig. 2 illustrates the principal steps in DISC formation and activation of the caspase cascade.

\section{Modulators of DISC formation}

A soluble decoy receptor called DcR3 was identified and shown to bind with Fas ligand but not with the other death ligands TNF, TRAIL or TWEAK. The gene coding for DcR3 is located on chromosome 20 and this locus is often amplified in colon cancer [23]. About half of all gastrointestinal tract carcinomas and lung cancers overexpress DcR3 suggesting that DcR3 amplification can promote tumour survival [23, 61 and 62]. DcR3 sequesters and inactivates membrane-bound Fas ligand on adjacent cells and infiltrating tumour cells and prevents activation of Fas receptor. Patients with gastrointestinal tract carcinomas that overexpress DcR3 have a significantly shortened mean duration of survival than patients with tumours expressing normal levels of DcR3 [62]. Human keratinocytes overexpress DcR3, and expression is rapidly decreased in cells following ultraviolet $B$ irradiation [63]. The signalling pathways responsible for DcR3 expression have not been identified yet and understanding the pathways responsible for decreasing expression of DcR3 in response to UVB irradiation may identify novel therapeutic targets against gastrointestinal tract carcinomas.

Expression of FADD can also regulate the sensitivity of cells to Fas-mediated apoptosis by altering the levels of effector caspases cleaved in response to Fas receptor activation. Even though FADD is a key component of Fas receptor signalling, expression is rarely decreased in tumour cells because expression of FADD is also required for cell cycle progression [64 and 65]. However, a number of cellular insults including actinomycin D, UV irradiation and heat shock have been shown to increase expression of FADD in hepatocytes [66].

Post-translational modification of FADD by PKC has also been shown to regulate Fas-receptormediated apoptosis in cells by inhibiting complete DISC formation following Fas receptor activation [67, 68 and 69]. The atypical protein kinase $C$ zeta (PKC) appears to play a central role in this process. Phosphorylation of FADD by PKC reduced DISC formation in cells following Fas receptor oligomerisation. Inhibition of Fas receptor-mediated apoptosis was reversed by overexpressing the PKC inhibiting protein prostate apoptosis responsive 4 (PAR-4) [70]. PAR-4 overexpression was also found to enhance the trafficking and activation of Fas receptor and Fas ligand in prostate cancer cells. This suggests that PKC may inhibit Fas-receptor-mediated apoptosis at several stages in the pathway upstream of caspase 8 activation [71]. PKC activity is implicated with tumour progression in a number of cancers by increasing proliferation and increasing resistance to apoptosis. PKC\& activity was increased in Ras-transformed fibroblasts as a direct result of decreased PAR-4 expression [72] and has been implicated as a mediator of a number of mitogenic signals associated with Ras transformation [73 and 74]. In addition, an increase in the activity of PKC乡 has been identified in a number of tumours including prostate cancer [75] and hepatocellular carcinomas [76], and expression correlates well with patients with invasive bladder cancer [77]. 
Another FADD interacting kinase called homeodomain-interacting protein kinase 3/FADD interacting serine/threonine kinase (HIPK3/FIST) has also been implicated in regulating DISC formation in vivo. HIPK3 belongs to a family of nuclear kinases with at least two other members, HIPK1 and HIPK2. HIPK3 has been shown to interact with and phosphorylate FADD in cells [78] while HIPK2 can associate with TRADD [79]. This suggests a role for these kinases in regulating death-receptormediated apoptosis. HIPK3 overexpression was shown to inhibit Fas-mediated JNK activation but did not affect apoptosis in 293T cells [78]. Although JNK activation is not required for Fas-mediated apoptosis in some cell lines [80, 81 and 82], the sensitivity to Fas-mediated apoptosis increases in other cell lines following JNK activation [83, 84, 85 and 86]. Therefore, overexpression of HIPK3 may inhibit activation of JNK and subsequently decrease the sensitivity to Fas-mediated apoptosis in some cell lines. Interestingly, several multidrug-resistant cell lines display increased HIPK3 activity [87 and 88].

In contrast with FADD, the expression of caspase 8 is often decreased in cells resistant to Fasmediated apoptosis. Hyper-methylation of the caspase 8 gene is frequently accompanied by loss of caspase 8 expression in a number of tumours, including retinoblastomas and neuroblastomas. It is believed that by methylating key residues in the caspase 8 gene, cells can negatively regulate transcription [89]. However, while DNA methylation has been associated with regulating gene expression, it is also possible that it is just a side effect of decreased transcription. Alternative splicing of caspase 8 has also been shown to inhibit Fas-mediated apoptosis. The splice variant caspase $8 \mathrm{~L}$ contains a functional DED but is missing key residues in the catalytic site and is catalytically inactive. Overexpression of caspase $8 \mathrm{~L}$ was found to increase resistance of Jurkat cells to Fas-mediated apoptosis by interfering with caspase 8 binding to FADD and functional DISC assembly [90].

Caspase $8 \mathrm{~L}$ functions in a similar fashion to another inhibitor of Fas-mediated apoptosis called FLICE inhibitory protein (FLIP). FLIP was first identified as a viral protein (VFLIP) and was found to inhibit Fas-mediated apoptosis when overexpressed in cells [91]. Cellular homologues were quickly identified and two major isoforms have been characterised, a short (FLIPS) and a long (FLIPL) isoform [92]. Although coded by separate genes, FLIP share sequence homology with caspase 8 and possess a functional DED that can bind to the DED on FADD in competition with caspase 8. Like caspase 8L, FLIPL and FLIPS are catalytically inactive and can inhibit procaspase 8 processing and activation at the DISC when overexpressed in vivo [93]. Activation of a key transcription factor involved in cell survival called NF-KB can upregulate FLIP expression [94] and inhibit Fas-mediated apoptosis [95]. Endogenous FLIPL is expressed at only 1\% that of endogenous Procaspase 8 in many cell lines [93], and at low levels of expression FLIPL appears to enhance and not inhibit Fas-mediated apoptosis by enhancing caspase 8 recruitment and DISC formation [95]. Procaspase 8 bound to FLIPL can be partially processed, and heterodimers of FLIPL and caspase 8 have been found to retain some protease activity [96]. The preferred substrate for heterodimers of FLIPL and caspase 8 is a protein kinase called RIP.

RIP1 was initially identified as a death-domain-containing, Fas receptor-interacting protein in two hybrid protein assays. Transient overexpression of RIP1 caused transfected cells to undergo apoptosis [28], and activation of RIP1 may explain in part why endogenous FLIPL expression enhances Fas-mediated apoptosis. RIP1 has been shown to initiate a caspase-independent mechanism for Fas-mediated cell death in T cells when co-expressed with FADD [97]. In addition, 
caspase 8-mediated cleavage of RIP1 produces a C-terminal fragment that appears to enhance apoptosis through enhanced DISC formation [98]. RIP1 belongs to a family with at least three other members that include RIP2 [99, 100 and 101], RIP3 [102 and 103] and RIP4 [104]. All four members of RIP contain a conserved $\mathrm{N}$-terminal kinase domain and each member contains a unique $\mathrm{C}$-terminal sequence responsible for subcellular localisation and function. A caspase activation and recruitment domain (CARD) domain is located at the C-terminus of RIP2 and is required for the apoptotic activity of RIP2. RIP2 is recruited to TNFR1 through the family of TRAF adaptor proteins and may also be involved in DISC formation of other death receptors [99]. However, recent reports suggest that the principal function of RIP2 in vivo is the activation of caspase 1 and IL-1 $\beta$ production during an innate immune response [105, 106 and 107]. RIP3 is also recruited to the TNFR1 receptor through its unique C-terminus that binds with RIP1. RIP3 inhibits RIP1-mediated NF-KB activation following TNFR1 activation and regulates RIP1 pro-apoptotic function [103 and 108]. The recently identified RIP4 contains $11 \mathrm{C}$-terminal ankyrin repeats. The ankyrin repeat domain is believed to regulate the activity of RIP4, and cleavage by caspases during Fas-mediated apoptosis has been shown to prevent the activation of the NF-KB survival pathway [104].

Another Fas-interacting protein that was identified by two-hybrid screening is DAXX. Transient expression of DAXX increases Fas-mediated apoptosis in 293, HeLa, L929 and HT1080 cell lines [29 and 109] while a truncated, dominant-negative form of DAXX was found to inhibit Fas-mediated apoptosis [109 and 110]. DAXX binds to the death domain of the Fas receptor and can activate the JNK kinase cascade independent of caspase 8 activation by recruiting and activating the upstream kinase ASK1 [54 and 56]. Activation of JNK was found to accelerate Fas-mediated apoptosis in various cell lines [83, 84, 85 and 86]. Overexpression of the small heat shock protein HSP27 was found to abrogate the interaction between ASK1 and DAXX. Furthermore, HSP27 expression can inhibit JNK activation following Fas receptor activation and protects against Fas-mediated apoptosis [110]. Neither DAXX nor RIP was found to be necessary for Fas-mediated apoptosis in lymphoma cell lines [111]. This suggests that both proteins can modulate sensitivity to Fas-mediated apoptosis but are not essential components of Fas-mediated apoptosis in all cell lines. By enhancing DISC formation and propagating apoptotic signals, these proteins appear to enhance the sensitivity of some cell lines with resistance to Fas-mediated apoptosis.

DAXX can bind with and undergo covalent modification by SUMO-1, a ubiquitin-like protein that was found to associate with the death domain of Fas receptor. Overexpression of SUMO-1 can protect against Fas-mediated apoptosis in BJAB cells [112]. Modification of proteins by SUMO-1 can have a variety of effects including changes in stability and subcellular localisation [113]. However, modification with SUMO-1 was not found to alter the stability or subcellular localisation of DAXX [114 and 115]. Instead, modification of PML by SUMO-1 sequesters DAXX in nuclear domains (ND-10 domains) and may inhibit the pro-apoptotic function associated with cytoplasmic DAXX. SUMO-1 can also modify the TRADD binding kinase HIPK2 [116]. Identification of other proteins modified by SUMO-1 should help to explain the mechanism by which SUMO-1 can protect cells from Fasmediated apoptosis.

Like RIP and DAXX, mouse Fas-associated factor 1 (FAF1) was first identified using Fas receptor as bait in a two hybrid screening assays [117]. Different methods were used to identify human and quail homologues and these were also found to interact with the intracellular domain of Fas receptor both in vitro and in vivo [118 and 119]. Overexpression of FAF1 was not found to induce 
apoptosis in transfected L-cells. Instead, the sensitivity of cells to Fas ligand was found to be enhanced in cells overexpressing FAF1 [117]. FAF1 has a ubiquitin-like domain but, in contrast with SUMO-1, this domain is pro-apoptotic in vivo [118]. Casein kinase 2 can phosphorylate FAF1 at several residues in vitro and in vivo but the function of this has not yet been identified [120].

\section{Modulators of Fas receptor and Fas ligand expression}

A common mechanism employed by cells to increase or decrease the sensitivity to Fas-mediated apoptosis is the regulated cell surface expression of Fas receptor and Fas ligand. Alternative splicing, protease-mediated cleavage, gene expression and sequestering of Fas receptor and Fas ligand have been found to regulate Fas-mediated apoptosis and are described below and outlined in Fig. 3.

Fas receptor is expressed at a single locus on chromosome 10 in human cells and chromosome 19 in mouse cells. At least eight splice variants and seven distinct isoforms of Fas receptor have been identified in human cells and arise from alternative splicing of Fas receptor RNA. Only isoform 1 encodes the functional, full-length protein and it is 335 amino acids in length. It consists of three cysteine-rich pseudo-repeats, a transmembrane domain and an intracellular death domain. Isoform 2 is 314 amino acids in length and encodes three cysteine-rich regions and a death domain, but is missing a transmembrane region. Isoforms 4 through 7 are also missing a transmembrane region and these soluble isoforms of Fas receptor may sequester and inactivate Fas ligand on adjacent cells and infiltrating cytotoxic T lymphocytes [121]. Overexpression of soluble Fas receptor has been implicated with the progression of prostate cancer [122], Melanoma [123] and bladder cancer [124] and is known to antagonise Fas-receptor-mediated apoptosis in vitro [121]. Isoform 3 is 220 amino acids long and contains three cysteine-rich pseudorepeats and a transmembrane region, but the cytoplasmic domain is truncated and does not contain a functional death domain. Overexpression of this isoform occurs in foetal thymocytes and may account for the high resistance in these cells to apoptosis following Fas receptor aggregation [125]. The mechanisms employed by cells to alter Fas RNA splicing and thus alter the sensitivity to Fas-mediated apoptosis appears to be an important process in vivo but remain to be characterised.

In contrast with Fas receptor, soluble Fas ligand is not generated by alternative splicing but is instead generated by post-translational modification of membrane bound Fas ligand at the cell surface. Matrix metalloproteinases are external serine proteases that cleave a wide range of extracellular substrates. Membrane-bound Fas ligand can be cleaved at a conserved cleavage site by matrix metalloproteinase-7 (MMP-7) into a less-active soluble form [126 and 127]. MMP-7 expression has been implicated in tumour initiation [128 and 129] and invasion [130]. Expression of MMP-7 in welldifferentiated tumour cells promotes resistance to Fas-mediated apoptosis [131]. In addition, overexpression of MMP-7 is believed to promote mammary tumour initiation and progression in mice by selecting for tumour cells resistant to Fas-mediated apoptosis [132]. Cells expressing low levels of a noncleavable variant of Fas ligand or inhibition of matrix metalloproteinases increases the sensitivity to Fas-mediated apoptosis [133]. Thus, MMP-7 can control the expression of Fas ligand on the surface of adjacent cells and infiltrating lymphocytes by cleaving membrane-bound Fas ligand. This appears to be a major mechanism by which MMP-7 regulates the sensitivity of cells to Fasmediated apoptosis. Increased resistance to Fas-mediated apoptosis by MMP-7 may also play a role in tumour progression. 
Regulation of soluble Fas receptor and Fas ligand expression has been implicated in modulating sensitivity of cells to Fas-mediated apoptosis. Transcription of the Fas receptor and Fas ligand genes can also be regulated by a number of signal pathways and this in turn can regulate the extent of cell surface Fas receptor and Fas ligand expression. Natural killer cells (NK cells) possess the ability to kill by Fas-mediated apoptosis and this is an important defence mechanism against tumour growth. By directly increasing Fas receptor expression, NK cells have been shown to increase the sensitivity of target cells to Fas-mediated apoptosis [134]. Cytotoxic T lymphocytes (CTL) can also promote transcription of Fas receptor in target cells through an interferon- $\gamma$ (IFN- - )-dependent mechanism [135]. Signal transducer and activator of transcription 1 (STAT1) is required for both IFN- $\gamma$-mediated upregulation of Fas receptor and Fas ligand expression and also for IFN- $\gamma$-dependent apoptosis in human tumour cells [136]. Another member of the STAT family, STAT3, can negatively regulate transcription of the Fas receptor. Expression of both STAT3 and another transcription factor, c-Jun, is required to inhibit Fas receptor transcription. Overexpression of either dominant-negative STAT3 or dominant-negative c-Jun was shown to increase the expression of Fas receptor [137]. Conversely, binding of c-Jun and activation transcription factor 2 (ATF2) to the Fas ligand promoter induces Fas ligand expression [138]. Upregulation of Fas ligand expression is associated with tumour progression and is believed to act as a defence against infiltrating lymphocytes [47, 139 and 140] and overexpression of either dominant-negative or dominant-active MAP/Erk kinase kinase 1 (MEKK1) demonstrated the role played by the c-Jun $\mathrm{N}$ terminal kinase (JNK) cascade in this process [138 and 141]. Activation of JNK has been demonstrated to upregulate Fas ligand expression and promote apoptosis during $\beta$-amyloid-induced neuronal apoptosis [142], during AICD after T cell receptor stimulation [85] and following survival factor withdrawal in neurons [86].

Given the importance of the Fas apoptotic pathway in controlling tumour growth, it is not surprising to discover that tumour-suppressing proteins and onco-proteins can directly regulate Fas receptor expression. Fas receptor can be upregulated following DNA damage by ionising radiation and genotoxic drugs in a P53-dependent manner [143 and 144]. A P53-responsive element was identified within the first intron of the Fas receptor gene in subsequent studies and wild-type P53 expression was found to be required for Fas receptor upregulation in response to anti-cancer drugs [145]. Basal expression of Fas receptor is also regulated by the onco-protein Ras. Overexpression of Ras was shown to decrease Fas receptor expression in vitro and in vivo [146]. Inhibition of Ras using Farnesyltransferase inhibitors was found to upregulate Fas receptor expression in Ras-transformed cells [147].

In addition to modulating the transcription and alternative splicing of Fas receptor mRNA, the expression of cell surface Fas receptor can be regulated by altering intracellular trafficking of Fas receptor. Fas receptor is a membrane-bound protein and subcellular trafficking is an important mechanism for regenerating and recycling Fas receptor. In addition, intracellular stores of Fas receptor may translocate to the plasma membrane in response to apoptotic stimuli [148 and 149]. FAP-1 is also known as protein-tyrosine phosphatase, nonreceptor-type, 13 (PTNP13) and was found to associate with the carboxy terminal 15 amino acids of human Fas receptor [150]. In vitro inhibition of the interaction between FAP-1 and Fas using synthetic peptides demonstrated that the amino acid motif SLV, found at the carboxy terminus of the Fas receptor, was both sufficient and necessary for binding to FAP-1 [151]. Mouse Fas receptor does not contain this C-terminal motif and does not interact with either mouse FAP-1 (PTP-BL) or human FAP-1 when overexpressed in cells [152]. Overexpression of FAP-1 increased the resistance of Fas-sensitive human cell lines to Fas- 
mediated apoptosis [150, 153 and 154]. In addition, Fas-resistant memory T cells were found to express higher levels of FAP-1 mRNA than Fas-sensitive naive T cells, and resting T cells expressed higher levels of FAP-1 mRNA than activated T cells, suggesting that FAP-1 expression regulates the sensitivity of cells to Fas-mediated apoptosis [155]. FAP-1 was found to sequester Fas receptor in the Golgi complex when overexpressed in pancreatic cancer cells and this prevents the translocation Fas receptor from intracellular stores to the plasma membrane following stimulation with Fas ligand. FAP-1 was not detected at the DISC of Fas-stimulated cells, suggesting that the sequestration of Fas receptor and ineffective DISC formation due to low surface expression of Fas receptor is the principle mechanism by which FAP-1 interferes with Fas-mediated apoptosis [154].

\section{Conclusion}

Regulation of the Fas receptor is important in both development and disease. Various diverse processes including altered gene expression, mRNA splice variants and signal transduction pathways control the sensitivity of cells to Fas ligand. Dysfunction of Fas receptor signalling occurs in many cancers and by studying the defects of Fas receptor signalling a variety of potential therapeutic targets have been identified. For example, the expression of sFasR has been used to predict clinical outcome in patients with various cancers, including gastrointestinal carcinomas [156] and prostate carcinoma [122]. MMP-7 expression is associated with tumour metastasis and various inhibitors of MMP-7 have been shown to delay metastasis and increase sensitivity of tumour cells to Fas ligand in mice [132]. By identifying the defective pathways in tumours for Fas receptor signalling, therapies can be designed to overcome the resistance of tumours to Fas ligand and this could improve the clinical outcome in patients when used in combination with standard chemotherapy. Understanding the complex regulation of Fas-mediated apoptosis is crucial to this process.

\section{Acknowledgements}

The Irish Cancer Society and Enterprise Ireland are acknowledged.

\section{References}

1. N. Joza, G. Kroemer and J.M. Penninger. Trends Genet. 18 (2002), pp. 142-149.

2. I. Herr and K.M. Debatin. Blood 98 (2001), pp. 2603-2614.

3. D.W. Nicholson. Cell Death Differ. 6 (1999), pp. 1028-1042.

4. B.B. Wolf and D.R. Green. J. Biol. Chem. 274 (1999), pp. 20049-20052.

5. P.H. Krammer. Adv. Immunol. 71 (1999), pp. 163-210.

6. P. Golstein. Curr. Biol. 7 (1997), pp. R750-R753.

7. T.S. Griffith and D.H. Lynch. Curr. Opin. Immunol. 10 (1998), pp. 559-563.

8. K. Schulze-Osthoff, D. Ferrari, M. Los, S. Wesselborg and M.E. Peter. Eur. J. Biochem. 254 (1998), pp. 439-459.

9. H.T. Idriss and J.H. Naismith. Microsc. Res. Tech. 50 (2000), pp. 184-195.

10. P.W. Gray, K. Barrett, D. Chantry, M. Turner and M. Feldmann. Proc. Natl. Acad. Sci. U. S. A. 87 (1990), pp. 7380-7384.

11. H. Loetscher, Y.C. Pan, H.W. Lahm, R. Gentz, M. Brockhaus, H. Tabuchi et al.. Cell 61 (1990), pp. 351-359.

12. Y. Nophar, O. Kemper, C. Brakebusch, H. Englemann, R. Zwang, D. Aderka et al.. EMBO J. 9 (1990), pp. 3269-3278. 
13. T.J. Schall, M. Lewis, K.J. Koller, A. Lee, G.C. Rice, G.H. Wong et al.. Cell 61 (1990), pp. 361370.

14. C.A. Smith, T. Davis, D. Anderson, L. Solam, M.P. Beckmann, R. Jerzy et al.. Science 248 (1990), pp. 1019-1023.

15. N. Itoh, S. Yonehara, A. Ishii, M. Yonehara, S. Mizushima, M. Sameshima et al.. Cell 66 (1991), pp. 233-243.

16. S.A. Marsters, J.P. Sheridan, C.J. Donahue, R.M. Pitti, C.L. Gray, A.D. Goddard et al.. Curr. Biol. 6 (1996), pp. 1669-1676.

17. G. Pan, J. Ni, Y.F. Wei, G. Yu, R. Gentz and V.M. Dixit. Science 277 (1997), pp. 815-818.

18. H. Walczak, M.A. Degli-Esposti, R.S. Johnson, P.J. Smolak, J.Y. Waugh, N. Boiani et al.. EMBO J. 16 (1997), pp. 5386-5397.

19. G.S. Wu, T.F. Burns, E.R. McDonald, III, W. Jiang, R. Meng, I.D. Krantz et al.. Nat. Genet. 17 (1997), pp. 141-143.

20. G.R. Screaton, J. Mongkolsapaya, X.N. Xu, A.E. Cowper, A.J. McMichael and J.I. Bell. Curr. Biol. 7 (1997), pp. 693-696.

21. G. Pan, J.H. Bauer, V. Haridas, S. Wang, D. Liu, G. Yu et al.. FEBS Lett. 431 (1998), pp. 351356.

22. S.A. Marsters, J.P. Sheridan, R.M. Pitti, A. Huang, M. Skubatch, D. Baldwin et al.. Curr. Biol. 7 (1997), pp. 1003-1006.

23. R.M. Pitti, S.A. Marsters, D.A. Lawrence, M. Roy, F.C. Kischkel, P. Dowd et al.. Nature 396 (1998), pp. 699-703.

24. A. Ashkenazi and V.M. Dixit. Curr. Opin. Cell Biol. 11 (1999), pp. 255-260.

25. A.M. Chinnaiyan, K. O'Rourke, M. Tewari and V.M. Dixit. Cell 81 (1995), pp. 505-512.

26. M.P. Boldin, E.E. Varfolomeev, Z. Pancer, I.L. Mett, J.H. Camonis and D. Wallach. J. Biol. Chem. 270 (1995), pp. 7795-7798.

27. H. Hsu, J. Xiong and D.V. Goeddel. Cell 81 (1995), pp. 495-504.

28. B.Z. Stanger, P. Leder, T.H. Lee, E. Kim and B. Seed. Cell 81 (1995), pp. 513-523.

29. X. Yang, R. Khosravi-Far, H.Y. Chang and D. Baltimore. Cell 89 (1997), pp. 1067-1076.

30. M.S. Sheikh and A.J. Fornace, Jr.. Leukemia 14 (2000), pp. 1509-1513.

31. K. Newton, A.W. Harris and A. Strasser. EMBO J. 19 (2000), pp. 931-941.

32. J.C. Rathmell, S.E. Townsend, J.C. Xu, R.A. Flavell and C.C. Goodnow. Cell 87 (1996), pp. 319329.

33. A. Bras, A.C. Martinez and E. Baixeras. J. Immunol. 159 (1997), pp. 3168-3177.

34. L. Van Parijs, Y. Refaeli, A.K. Abbas and D. Baltimore. Immunity 11 (1999), pp. 763-770.

35. Y. Oshimi, S. Oda, Y. Honda, S. Nagata and S. Miyazaki. J. Immunol. 157 (1996), pp. 29092915.

36. P. Bjorck, J. Banchereau and L. Flores-Romo. Int. Immunol. 9 (1997), pp. 365-372.

37. J.P. Medema, R.E. Toes, C. Scaffidi, T.S. Zheng, R.A. Flavell, C.J. Melief et al.. Eur. J. Immunol. 27 (1997), pp. 3492-3498.

38. F. Rieux-Laucat, F. Le Deist, C. Hivroz, I.A. Roberts, K.M. Debatin, A. Fischer et al.. Science 268 (1995), pp. 1347-1349.

39. G.H. Fisher, F.J. Rosenberg, S.E. Straus, J.K. Dale, L.A. Middleton, A.Y. Lin et al.. Cell 81 (1995), pp. 935-946.

40. E. Song, S.K. Lee, J. Wang, N. Ince, N. Ouyang, J. Min et al.. Nat. Med. 9 (2003), pp. 347-351. 
41. A. Martin-Villalba, I. Herr, I. Jeremias, M. Hahne, R. Brandt, J. Vogel et al.. J. Neurosci. 19 (1999), pp. 3809-3817.

42. T. Herdegen, F.X. Claret, T. Kallunki, A. Martin-Villalba, C. Winter, T. Hunter et al.. J. Neurosci. 18 (1998), pp. 5124-5135.

43. J. Qiu, M.J. Whalen, P. Lowenstein, G. Fiskum, B. Fahy, R. Darwish et al.. J. Neurosci. 22 (2002), pp. 3504-3511.

44. C. Raoul, B. Pettmann and C.E. Henderson. Curr. Opin. Neurobiol. 10 (2000), pp. 111-117.

45. H. Kitaura, N. Nagata, Y. Fujimura, H. Hotokezaka, N. Yoshida and K. Nakayama. J. Immunol. 169 (2002), pp. 4732-4738.

46. L.E. French and J. Tschopp. Semin. Cancer Biol. 12 (2002), pp. 51-55.

47. S. Strand, W.J. Hofmann, H. Hug, M. Muller, G. Otto, D. Strand et al.. Nat. Med. 2 (1996), pp. 1361-1366.

48. M.J. Pinkoski and D.R. Green. Curr. Opin. Genet. Dev. 10 (2000), pp. 114-119.

49. A. Algeciras-Schimnich, L. Shen, B.C. Barnhart, A.E. Murmann, J.K. Burkhardt and M.E. Peter. Mol. Cell. Biol. 22 (2002), pp. 207-220.

50. P. Schneider, N. Holler, J.L. Bodmer, M. Hahne, K. Frei, A. Fontana et al.. J. Exp. Med. 187 (1998), pp. 1205-1213.

51. U. von Reyher, J. Strater, W. Kittstein, M. Gschwendt, P.H. Krammer and P. Moller. Cancer Res. 58 (1998), pp. 526-534.

52. M.R. Sprick, E. Rieser, H. Stahl, A. Grosse-Wilde, M.A. Weigand and H. Walczak. EMBO J. 21 (2002), pp. 4520-4530.

53. K. Tobiume, A. Matsuzawa, T. Takahashi, H. Nishitoh, K. Morita, K. Takeda et al.. EMBO Rep. 2 (2001), pp. 222-228.

54. H.Y. Chang, H. Nishitoh, X. Yang, H. Ichijo and D. Baltimore. Science 281 (1998), pp. 18601863.

55. S.J. Charette, H. Lambert and J. Landry. J. Biol. Chem. 276 (2001), pp. 36071-36074.

56. Y.G. Ko, Y.S. Kang, H. Park, W. Seol, J. Kim, T. Kim et al.. J. Biol. Chem. 276 (2001), pp. 3910339106.

57. M. Ahmad, S.M. Srinivasula, L. Wang, R.V. Talanian, G. Litwack, T. Fernandes-Alnemri et al.. Cancer Res. 57 (1997), pp. 615-619.

58. K. Wang, X.M. Yin, D.T. Chao, C.L. Milliman and S.J. Korsmeyer. Genes Dev. 10 (1996), pp. 2859-2869.

59. A. Gross, X.M. Yin, K. Wang, M.C. Wei, J. Jockel, C. Milliman et al.. J. Biol. Chem. 274 (1999), pp. 1156-1163.

60. C. Scaffidi, I. Schmitz, J. Zha, S.J. Korsmeyer, P.H. Krammer and M.E. Peter. J. Biol. Chem. 274 (1999), pp. 22532-22538.

61. C. Bai, B. Connolly, M.L. Metzker, C.A. Hilliard, X. Liu, V. Sandig et al.. Proc. Natl. Acad. Sci. U. S. A. 97 (2000), pp. 1230-1235.

62. Y. Takahama, Y. Yamada, K. Emoto, H. Fujimoto, T. Takayama, M. Ueno et al.. Gastric Cancer 5 (2002), pp. 61-68.

63. T. Maeda, C. Hao and V.A. Tron. J. Cutan. Med. Surg. 5 (2001), pp. 294-298.

64. M. Zornig, A.O. Hueber and G. Evan. Curr. Biol. 8 (1998), pp. 467-470.

65. A.O. Hueber, M. Zornig, A.M. Bernard, M. Chautan and G. Evan. J. Biol. Chem. 275 (2000), pp. 10453-10462. 
66. P.K. Kim, Y. Wang, A. Gambotto, Y.M. Kim, R. Weller, B.S. Zuckerbraun et al.. J. Biol. Chem. 277 (2002), pp. 38855-38862.

67. M.C. Ruiz-Ruiz, M. Izquierdo, G. de Murcia and A. Lopez-Rivas. Eur. J. Immunol. 27 (1997), pp. $1442-1450$.

68. C.M. Mueller and D.W. Scott. J. Immunol. 165 (2000), pp. 1854-1862.

69. M. Gomez-Angelats and J.A. Cidlowski. J. Biol. Chem. 276 (2001), pp. 44944-44952.

70. A. de Thonel, A. Bettaieb, C. Jean, G. Laurent and A. Quillet-Mary. Blood 98 (2001), pp. 3770-3777.

71. M. Chakraborty, S.G. Qiu, K.M. Vasudevan and V.M. Rangnekar. Cancer Res. 61 (2001), pp. 7255-7263.

72. M. Barradas, A. Monjas, M.T. Diaz-Meco, M. Serrano and J. Moscat. EMBO J. 18 (1999), pp. 6362-6369.

73. G. Bjorkoy, M. Perander, A. Overvatn and T. Johansen. J. Biol. Chem. 272 (1997), pp. 1155711565.

74. M.T. Diaz-Meco, J. Lozano, M.M. Municio, E. Berra, S. Frutos, L. Sanz et al.. J. Biol. Chem. 269 (1994), pp. 31706-31710.

75. P. Cornford, J. Evans, A. Dodson, K. Parsons, A. Woolfenden, J. Neoptolemos et al.. Am. J. Pathol. 154 (1999), pp. 137-144.

76. J.H. Tsai, Y.S. Hsieh, S.J. Kuo, S.T. Chen, S.Y. Yu, C.Y. Huang et al.. Cancer Lett. 161 (2000), pp. 171-175.

77. L. Langzam, R. Koren, R. Gal, V. Kugel, A. Paz, A. Farkas et al.. Am. J. Clin. Pathol. 116 (2001), pp. $377-385$.

78. V. Rochat-Steiner, K. Becker, O. Micheau, P. Schneider, K. Burns and J. Tschopp. J. Exp. Med. 192 (2000), pp. 1165-1174.

79. X. Li, Y. Wang, K.M. Debatin and H. Hug. Biochem. Biophys. Res. Commun. 277 (2000), pp. 513-517.

80. W. Low, A. Smith, A. Ashworth and M. Collins. Oncogene 18 (1999), pp. 3737-3741.

81. M.T. Abreu-Martin, A.A. Palladino, M. Faris, N.M. Carramanzana, A.E. Nel and S.R. Targan. Am. J. Physiol. 276 (1999), pp. G599-G605.

82. I. Herr, D. Wilhelm, T. Bohler, P. Angel and K.M. Debatin. Int. J. Cancer 80 (1999), pp. 417424.

83. J.F. Curtin and T.G. Cotter. Br. J. Cancer 87 (2002), pp. 1188-1194.

84. A.P. Costa-Pereira, S.L. McKenna and T.G. Cotter. Br. J. Cancer 82 (2000), pp. 1827-1834.

85. J. Zhang, J.X. Gao, K. Salojin, Q. Shao, M. Grattan, C. Meagher et al.. J. Exp. Med. 191 (2000), pp. 1017-1030.

86. H. Le-Niculescu, E. Bonfoco, Y. Kasuya, F.X. Claret, D.R. Green and M. Karin. Mol. Cell. Biol. 19 (1999), pp. 751-763.

87. D.A. Begley, M.B. Berkenpas, K.E. Sampson and I. Abraham. Gene 200 (1997), pp. 35-43.

88. K.E. Sampson, M.C. McCroskey and I. Abraham. J. Cell. Biochem. 52 (1993), pp. 384-395.

89. K. Harada, S. Toyooka, N. Shivapurkar, A. Maitra, J.L. Reddy, H. Matta et al.. Cancer Res. 62 (2002), pp. 5897-5901.

90. D. Himeji, T. Horiuchi, H. Tsukamoto, K. Hayashi, T. Watanabe and M. Harada. Blood 99 (2002), pp. 4070-4078.

91. M. Thome, P. Schneider, K. Hofmann, H. Fickenscher, E. Meinl, F. Neipel et al.. Nature 386 (1997), pp. 517-521. 
92. M. Irmler, M. Thome, M. Hahne, P. Schneider, K. Hofmann, V. Steiner et al.. Nature 388 (1997), pp. 190-195.

93. C. Scaffidi, I. Schmitz, P.H. Krammer and M.E. Peter. J. Biol. Chem. 274 (1999), pp. 15411548.

94. S. Kreuz, D. Siegmund, P. Scheurich and H. Wajant. Mol. Cell Biol. 21 (2001), pp. 3964-3973.

95. D.W. Chang, Z. Xing, Y. Pan, A. Algeciras-Schimnich, B.C. Barnhart, S. Yaish-Ohad et al.. EMBO J. 21 (2002), pp. 3704-3714.

96. O. Micheau, M. Thome, P. Schneider, N. Holler, J. Tschopp, D.W. Nicholson et al.. J. Biol. Chem. 277 (2002), pp. 45162-45171.

97. N. Holler, R. Zaru, O. Micheau, M. Thome, A. Attinger, S. Valitutti et al.. Nat. Immunol. 1 (2000), pp. 489-495.

98. J.W. Kim, E.J. Choi and C.O. Joe. Oncogene 19 (2000), pp. 4491-4499.

99. J.V. McCarthy, J. Ni and V.M. Dixit. J. Biol. Chem. 273 (1998), pp. 16968-16975.

100. N. Inohara, L. del Peso, T. Koseki, S. Chen and G. Nunez. J. Biol. Chem. 273 (1998), pp. 12296-12300.

101. M. Thome, K. Hofmann, K. Burns, F. Martinon, J.L. Bodmer, C. Mattmann et al.. Curr. Biol. 8 (1998), pp. 885-888.

102. X. Sun, J. Lee, T. Navas, D.T. Baldwin, T.A. Stewart and V.M. Dixit. J. Biol. Chem. 274 (1999), pp. 16871-16875.

103. P.W. Yu, B.C. Huang, M. Shen, J. Quast, E. Chan, X. Xu et al.. Curr. Biol. 9 (1999), pp. 539-542.

104. E. Meylan, F. Martinon, M. Thome, M. Gschwendt and J. Tschopp. EMBO Rep. 3 (2002), pp. 1201-1208.

105. A.I. Chin, P.W. Dempsey, K. Bruhn, J.F. Miller, Y. Xu and G. Cheng. Nature 416 (2002), pp. 190-194.

106. K. Kobayashi, N. Inohara, L.D. Hernandez, J.E. Galan, G. Nunez, C.A. Janeway et al.. Nature 416 (2002), pp. 194-199.

107. A. Druilhe, S.M. Srinivasula, M. Razmara, M. Ahmad and E.S. Alnemri. Cell Death Differ. 8 (2001), pp. 649-657.

108. X. Sun, J. Yin, M.A. Starovasnik, W.J. Fairbrother and V.M. Dixit. J. Biol. Chem. 277 (2002), pp. 9505-9511.

109. S. Torii, D.A. Egan, R.A. Evans and J.C. Reed. EMBO J. 18 (1999), pp. 6037-6049.

110. S.J. Charette, J.N. Lavoie, H. Lambert and J. Landry. Mol. Cell. Biol. 20 (2000), pp. 7602-7612.

111. A. Villunger, D.C. Huang, N. Holler, J. Tschopp and A. Strasser. J. Immunol. 165 (2000), pp. 1337-1343.

112. T. Okura, L. Gong, T. Kamitani, T. Wada, I. Okura, C.F. Wei et al.. J. Immunol. 157 (1996), pp. 4277-4281.

113. R.T. Hay. Trends Biochem. Sci. 26 (2001), pp. 332-333.

114. M.S. Jang, S.W. Ryu and E. Kim. Biochem. Biophys. Res. Commun. 295 (2002), pp. 495-500.

115. S.W. Ryu, S.K. Chae and E. Kim. Biochem. Biophys. Res. Commun. 279 (2000), pp. $6-$ 10.

116. Y.H. Kim, C.Y. Choi and Y. Kim. Proc. Natl. Acad. Sci. U. S. A. 96 (1999), pp. 1235012355. 
117. K. Chu, X. Niu and L.T. Williams. Proc. Natl. Acad. Sci. U. S. A. 92 (1995), pp. 1189411898.

118. S.W. Ryu and E. Kim. Biochem. Biophys. Res. Commun. 286 (2001), pp. 1027-1032.

119. T. Frohlich, W. Risau and I. Flamme. J. Cell. Sci. 111 Pt. 16 (1998), pp. 2353-2363.

120. H.H. Jensen, M. Hjerrild, B. Guerra, M.R. Larsen, P. Hojrup and B. Boldyreff. Int. J.

Biochem. Cell Biol. 33 (2001), pp. 577-589.

121. J. Cheng, T. Zhou, C. Liu, J.P. Shapiro, M.J. Brauer, M.C. Kiefer et al.. Science 263

(1994), pp. 1759-1762.

122. Y. Furuya, H. Fuse and M. Masai. Anticancer Res. 21 (2001), pp. 3595-3598.

123. S. Ugurel, G. Rappl, W. Tilgen and U. Reinhold. Clin. Cancer Res. 7 (2001), pp. 12821286.

124. Y. Mizutani, O. Yoshida and B. Bonavida. J. Urol. 160 (1998), pp. 571-576.

125. M. Jenkins, M. Keir and J.M. McCune. J. Biol. Chem. 275 (2000), pp. 7988-7993.

126. M. Tanaka, T. Itai, M. Adachi and S. Nagata. Nat. Med. 4 (1998), pp. 31-36.

127. W.C. Powell, B. Fingleton, C.L. Wilson, M. Boothby and L.M. Matrisian. Curr. Biol. 9 (1999), pp. 1441-1447.

128. K. Shigemasa, H. Tanimoto, K. Sakata, N. Nagai, T.H. Parmley, K. Ohama et al.. Med. Oncol. 17 (2000), pp. 52-58.

129. L.A. Rudolph-Owen, R. Chan, W.J. Muller and L.M. Matrisian. Cancer Res. 58 (1998), pp. 5500-5506.

130. H. Yamamoto, Y. Adachi, F. Itoh, S. Iku, K. Matsuno, M. Kusano et al.. Cancer Res. 59 (1999), pp. 3313-3316.

131. B. Fingleton, T. Vargo-Gogola, H.C. Crawford and L.M. Matrisian. Neoplasia 3 (2001), pp. 459-468.

132. T. Vargo-Gogola, B. Fingleton, H.C. Crawford and L.M. Matrisian. Cancer Res. 62 (2002), pp. 5559-5563.

133. P.G. Knox, A.E. Milner, N.K. Green, A.G. Eliopoulos and L.S. Young. J. Immunol. 170 (2003), pp. 677-685.

134. V. Screpanti, R.P. Wallin, H.G. Ljunggren and A. Grandien. J. Immunol. 167 (2001), pp. 2068-2073.

135. A. Mullbacher, M. Lobigs, R.T. Hla, T. Tran, T. Stehle and M.M. Simon. J. Immunol. 169 (2002), pp. 145-150.

136. X. Xu, X.Y. Fu, J. Plate and A.S. Chong. Cancer Res. 58 (1998), pp. 2832-2837.

137. V.N. Ivanov, M. Krasilnikov and Z. Ronai. J. Biol. Chem. 277 (2002), pp. 4932-4944.

138. M. Faris, K.M. Latinis, S.J. Kempiak, G.A. Koretzky and A. Nel. Mol. Cell. Biol. 18 (1998), pp. 5414-5424.

139. C. Belluco, G. Esposito, R. Bertorelle, R. Alaggio, L. Giacomelli, L.C. Bianchi et al.. Eur. J. Surg. Oncol. 28 (2002), pp. 120-125.

140. D. Cefai, R. Schwaninger, M. Balli, T. Brunner and C.D. Gimmi. Cell Death Differ. 8 (2001), pp. 687-695.

141. M. Faris, N. Kokot, K. Latinis, S. Kasibhatla, D.R. Green, G.A. Koretzky et al.. J. Immunol. 160 (1998), pp. 134-144.

142. Y. Morishima, Y. Gotoh, J. Zieg, T. Barrett, H. Takano, R. Flavell et al.. J. Neurosci. 21 (2001), pp. 7551-7560. 
143. M.A. Sheard, B. Vojtesek, L. Janakova, J. Kovarik and J. Zaloudik. Int. J. Cancer 73 (1997), pp. 757-762.

144. M.C. Ruiz-Ruiz and A. Lopez-Rivas. Cell Death Differ. 6 (1999), pp. 271-280.

145. M. Muller, S. Wilder, D. Bannasch, D. Israeli, K. Lehlbach, M. Li-Weber et al.. J. Exp. Med. 188 (1998), pp. 2033-2045.

146. R.G. Fenton, J.A. Hixon, P.W. Wright, A.D. Brooks and T.J. Sayers. Cancer Res. 58 (1998), pp. 3391-3400.

147. B. Zhang, G.C. Prendergast and R.G. Fenton. Cancer Res. 62 (2002), pp. 450-458.

148. M. Bennett, K. Macdonald, S.W. Chan, J.P. Luzio, R. Simari and P. Weissberg. Science 282 (1998), pp. 290-293.

149. T. Sodeman, S.F. Bronk, P.J. Roberts, H. Miyoshi and G.J. Gores. Am. J. Physiol.: Gastrointest Liver Physiol. 278 (2000), pp. G992-G999.

150. T. Sato, S. Irie, S. Kitada and J.C. Reed. Science 268 (1995), pp. 411-415. 151.

151. J. Yanagisawa, M. Takahashi, H. Kanki, H. Yano-Yanagisawa, T. Tazunoki, E. Sawa et al.. J. Biol. Chem. 272 (1997), pp. 8539-8545.

152. E. Cuppen, S. Nagata, B. Wieringa and W. Hendriks. J. Biol. Chem. 272 (1997), pp. 30215-30220.

153. Y. Li, H. Kanki, T. Hachiya, T. Ohyama, S. Irie, G. Tang et al.. Int. J. Cancer 87 (2000), pp. 473-479.

154. H. Ungefroren, M.L. Kruse, A. Trauzold, S. Roeschmann, C. Roeder, A. Arlt et al.. J. Cell. Sci. 114 (2001), pp. 2735-2746.

155. Y.W. Zhou, Y. Komada, H. Inaba, E. Azuma and M. Sakurai. Cell. Immunol. 186 (1998), pp. 103-110.

156. N.E. Kushlinskii, T.A. Britvin, S.G. Abbasova, A.G. Perevoshchikov, V.V. Prorokov, I.A. Kostanyan et al.. Bull. Exp. Biol. Med. 131 (2001), pp. 361-363.

\section{FIGURE LEGENDS}

Fig. 1. Schematic diagram depicting the death receptors Fas, TNF-R1, DR3, TRAIL-R1, TRAIL-R2 and DR6 and the decoy receptors DcR1, DcR2 and DcR3. The number of cysteine-rich pseudorepeats present is indicated by the number of extracellular domains for each receptor. Ligands that are known to bind to these receptors are all shown and are predominantly membrane bound. Some death receptors can bind with more than one ligand and some ligands bind to more than one receptor as indicated. Important adaptor proteins that are recruited to each receptor and that are involved in signal transduction are also indicated.

Fig. 2. Illustration depicting the major events during DISC formation. Microaggregates of Fas receptor are formed after binding with Fas ligand. Caspase 8 is activated and is required for the formation of large clusters. ASK1 and RIP activation during DISC formation promote apoptosis. Mitochondria serve as an amplification step in type II cells. Finally, receptor clusters are endocytosed and may be recycled.

Fig. 3. Schematic diagram identifying the major regulatory mechanisms of Fas receptor and Fas ligand expression and activation. Fas receptor is alternatively spliced, producing inhibitory isoforms including membrane bound isoform 3 and soluble Fas receptor isoforms that interfere with Fas receptor activation by Fas ligand. The extracellular protease MMP-7 can cleave Fas ligand at a 
conserved site. Soluble Fas ligand binds with Fas receptor but inhibits DISC formation . Stress stimuli include DNA damage and immune responses and can activate the JNK kinase cascade. JNK phosphorylates and activates C-Jun, P53 and ATF2 and increases the expression of Fas receptor and Fas ligand , . IFN- $\gamma$ is secreted by CTL and activates the transcription factor STAT1 . STAT1 upregulates Fas receptor expression and sensitises cells to CTL-mediated cell death. 


\section{Figure 1}

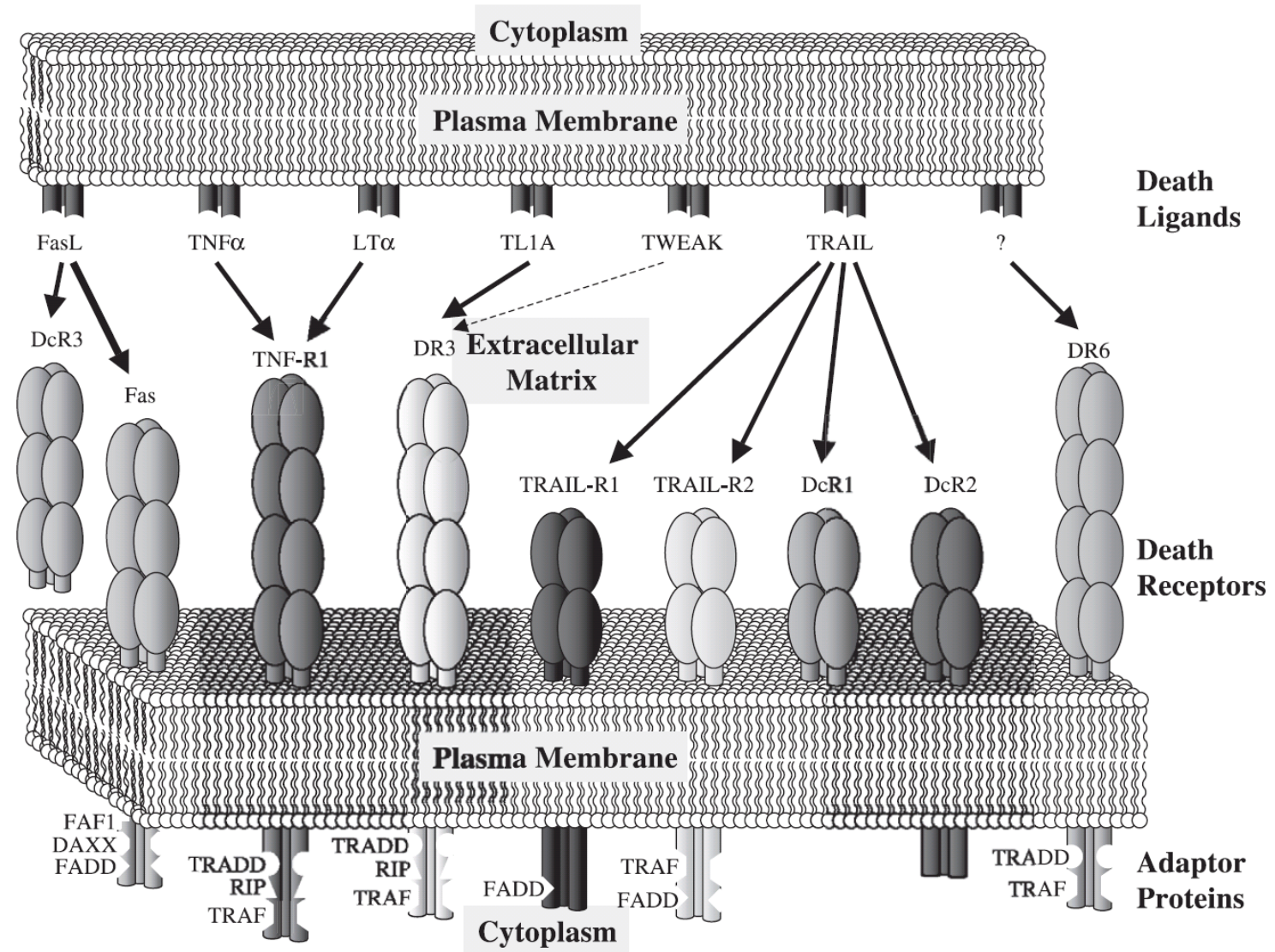


Figure 2

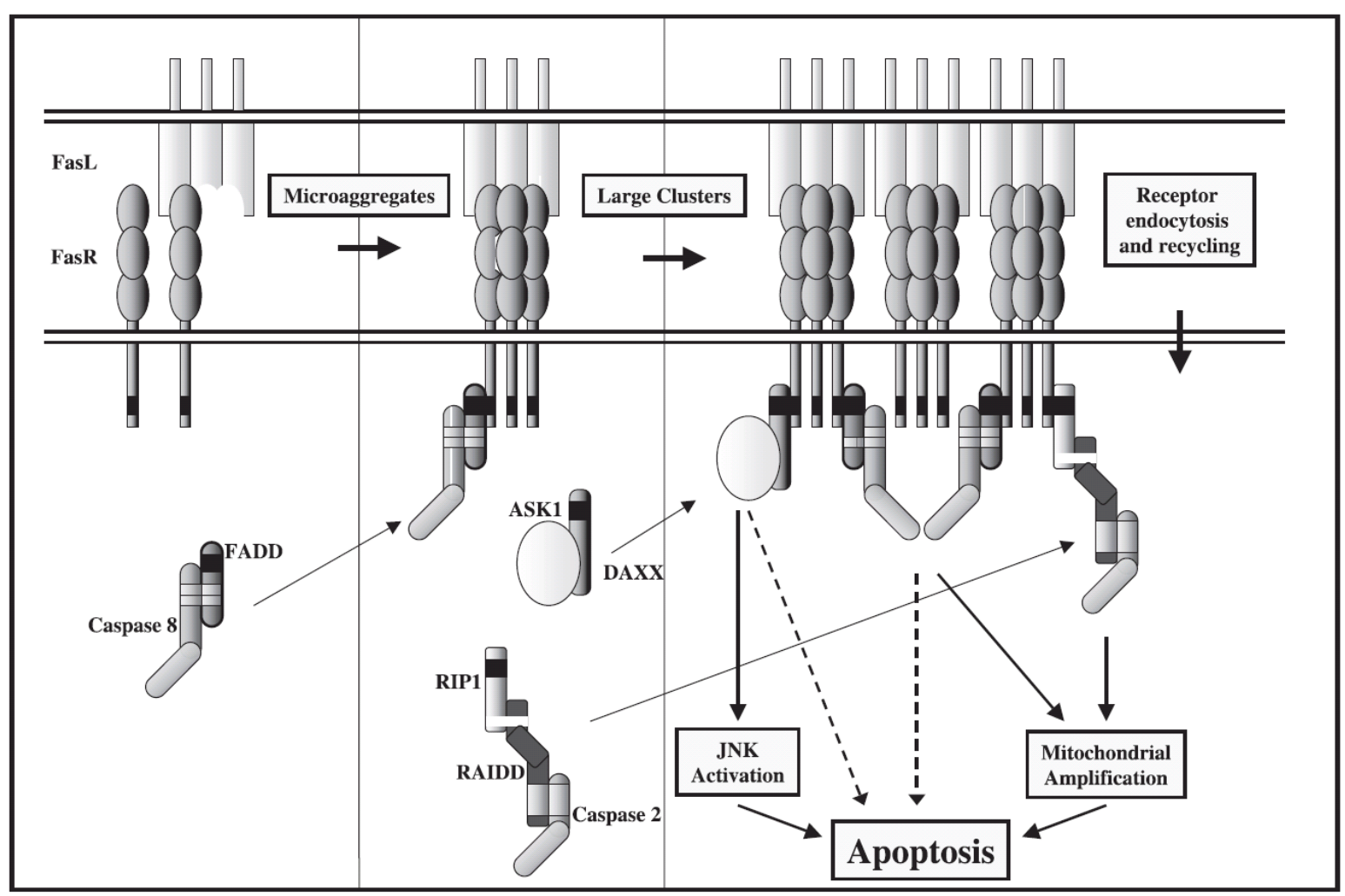


Figure 3

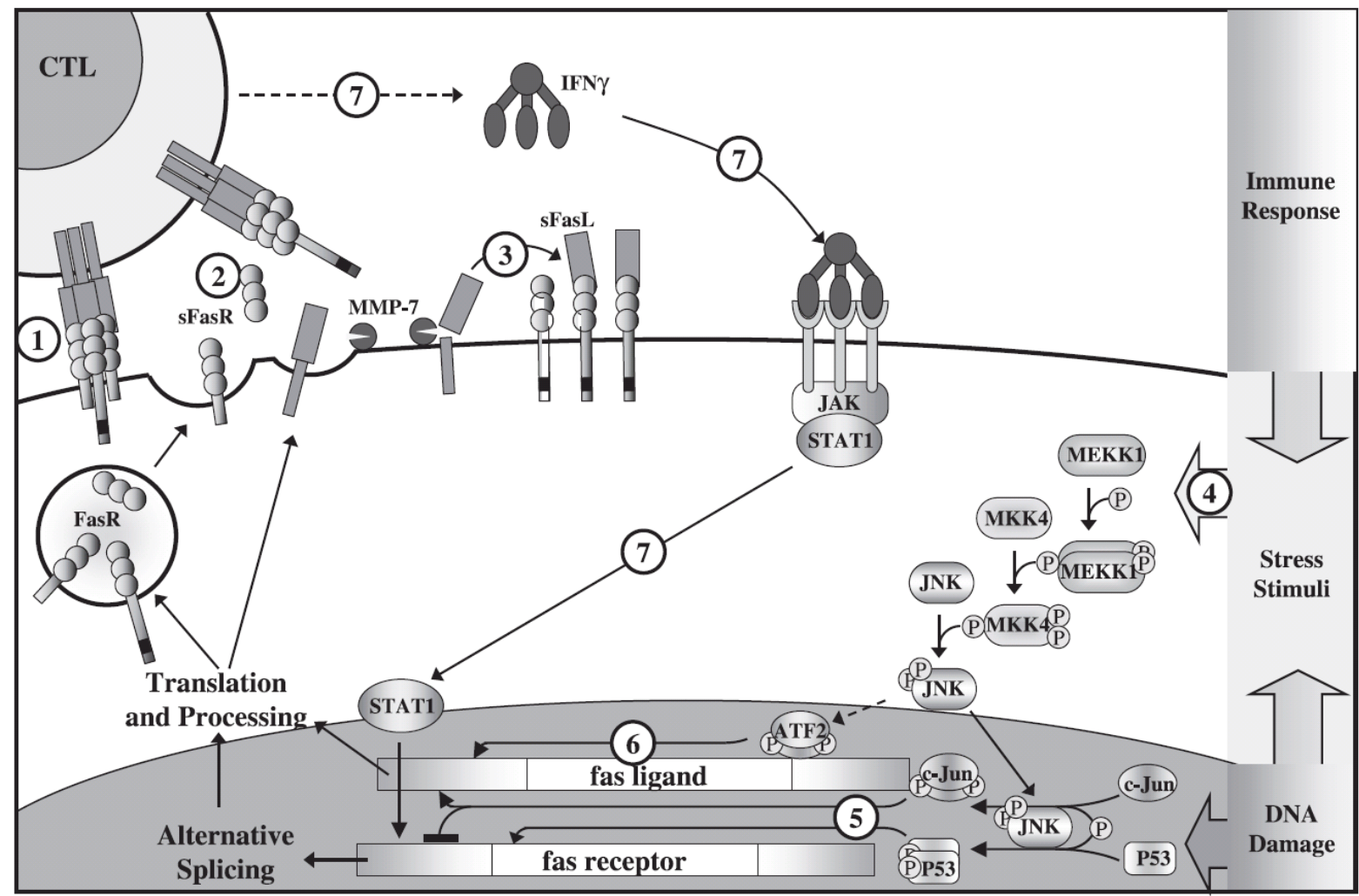

